\title{
EVALUATION OF CUSTOMER RELATIONSHIP SYSTEM EFFICIENCY: APPLYING OF TOTAL COST OF OWNERSHIP APPROACH
}

\author{
Regina Jasilioniené ${ }^{1}$, Rima Tamošiūnienè ${ }^{2}$ \\ Vilnius Gediminas Technical University, Saulètekio al. 11, LT-10223 Vilnius, Lithuania \\ E-mails: ${ }^{1}$ RJasilioniene@alna.lt; ${ }^{2}$ Rima.Tamosiuniene@vgtu.lt \\ Received 7 February 2008; accepted 26 September 2009
}

\begin{abstract}
Calculating total cost of ownership (TCO) and benefits, building a business case and applying financial measurement methodologies help a company make right customer relationship system for investments solution and build compelling justification for its customer relationship system project. In addition, ongoing measurement of customer relationship system (CRS ) benefits ensures that an enterprise receives expected advantages and achieves strategic objectives.

In this paper peculiarities of TCO economic efficiency are analysed. Evaluation method application when developing, using and expanding CRS is being considered, strengths and weaknesses of cost-oriented approach are discussed. Authors present and interpret their empirical research results.
\end{abstract}

Keywords: customer relationship system (CRS), total cost of ownership (TCO), one-time costs, recurring costs.

\section{Introduction}

As a result of globalisation, companies face ever increasing global competition. Consumers may choose from an increasing variety of suppliers of goods and services: where to purchase food or spend their holidays, which suppliers of telecommunication services to use, where to borrow money or keep it, etc. The privatisation of former state monopolies and elimination of various limitations increase competition to an even greater extent and force companies to reduce their expenses. As accumulation means for fixed investment, which generally drives companies' growth (Tvaronavičius, Tvaronavičienè 2008), becomes more complicated, companies are forced to put emphasis on managerial tools enhancing client's satisfaction.

Over the past few decades, one may observe the emergence of the concept of the customer relationship management. With the current level of IT systems, we may just make a step back into the past and personalise mass marketing, sales, and customer service. If earlier the owner of a shop kept information about his 100 customers in his mind, the database of the contemporary customer relationship system (CRS) can store information about 100,000 customers and on the basis of historical information, the company can offer each customer what he needs. It is essential for the companies planning to develop a CRS to use adequate evaluation methods to identify the efficiency of the CRS under consideration and form the basis for objective decisions. In the case of a CRS that has already been implemented and is in use, it is also essential to apply relevant evaluation methods to carry out regular efficiency evaluation that must help disclose the actual advantages and disadvantages of the CRS in use and demonstrate the levels at which objectives have been implemented.

In order to implement customer-centric strategies, many organizations have turned to CRS software packages from various vendors such as Oracle, SAP, Microsoft, PeopleSoft, Frontrange, etc. (Conner 2001). Successful CRS implementation initiative is deemed to integrate companies' customer-facing processes, improve the efficiencies of their sales forces and call centres, and more accurately target their campaigns with the help of sophisticated customer data analytics. Therefore this initiative is deemed to place the company in a better financial position for the future. 
Companies are investing in CRS worldwide; however, the rate of successful such system implementations are below 30\% (Amerongen 2004; Bordoloi 2000; Chase 2001; Kim, H. and Kim, Y. 2007; Ramdas 2001; Silvon Software 2005; Korsakienè et al. 2008). Many organizations pursue expensive CRS initiatives without first understanding the challenges and costs involved. This approach often results in CRS projects that fail to meet measurable benefit objectives (Korsakienè 2009; Sūdžius 2007). The problem of CRS efficiency evaluation in the world and in Lithuania has been solved by using traditional economic efficiency evaluation methods such as Net Present Value (NPV), Internal Rate of Return (IRR), Return of Investment (ROI), Payback Period (PP), Total Cost of Ownership (TCO), Profitability Index (PI) or Economic Value Added (EVA).

The purpose of this study is to analyse TCO as financial CRS efficiency evaluation tool when developing, using, and expanding a CRS, and determine strengths and weaknesses of this cost-oriented approach.

To achieve the purpose of this study, research methods were used: scientific and practical literature analysis and generalization, and empirical research of Lithuanian companies.

\section{CRS investment justification issues}

Justifying the cost of CRS implementation project is not like doing a financial analysis on capital goods. A milling machine, for example, has readily identifiable acquisition and operating costs, and performance specifications can be used to accurately forecast productivity gains.

CRS has uncertain cost categories, no standards for valuing funds flows, a changing product, and a varying life. As Cooper (2005) states, this creates several unique cost justification issues:

1) High penalty costs. CRS is a high risk endeavour because companies are betting their revenue stream on the project. Service is both a satisfier and a dissatisfier. It takes consistently great service to generate customer loyalty, but only one bad interaction to create dissatisfaction and customer loss.

Enterprise resource planning systems are mostly inward-facing, where marginal efficiencies in traditional processes can be generated, and where systems can be run side-by-side throughout the conversion stage. Customer relationship systems are customer-facing and have a direct effect on customer satisfaction. Marketing, sales and customer service systems can not be run concurrently during a cut-over. Management of customer relationships is either living or it is not. That what is delivered by implementation of CRS is what customers and prospects experience.

The penalty for mishandling the customer relationship management interaction is more than just the cost of a botched transaction. It is the potential lost revenue from a now impaired relationship with customers. That is why customer relationship management decisions are actually justifications based upon customer satisfaction expectations. For many organizations, good service is the requirement to stay in business, and integrated CRS is necessary to deliver the level of service customers are demanding. The ultimate cost of refusing to implement CRS is a reduction in organizational competitiveness, viability and longevity.

2) Slow results. There is some disagreement among analysts about how quickly CRS benefits accrue. The differences between internal and external benefits are at issue. Internal operational benefits begin at implementation. Improving call center efficiency, increasing field service utilization, or moving sales inquiries to the Web can generate immediate savings. But these marginal improvements in operations are often not enough to fully evaluate integrated CRS projects. Customer revenue benefits occur some time later in the CRS project's life cycle. Analysts estimate that true payback justification can take 12 months or more (Silvon Software 2005). Customer loyalty is generated from a series of pleasing marketing and sales contacts and service interactions. It requires time for a new CRS to positively influence customer behaviour, depending upon the applicable buying cycle.

3) Benefit time frame exceeds CRS as project life cycle. Although CRS results can be slow in arriving, they can also continue for a very long time. Inherent in the above discussion of penalty costs is the concept of "lifetime customer value." What this suggests is that the benefits or penalties of a CRS can accrue far beyond its life cycle. For instance, a specific Customer Interaction Center sales and support system may have a three-year life, but it is attracting (or repelling) customers who might have an average seven-year long relationship.

A good example is when a major toy retailer was unable to ship its e-commerce orders in time for Christmas. Parents were quoted as saying they would never again buy from the site or the company's stores. And this bad experience is likely to trickle down for decades as the children who were disappointed on this Christmas day remember this when deciding where to buy their children's toys in the coming years. 
The results of CRS projects closely linked to customers and revenues, may long outlive the useful lives of specific products and systems. A CRS justification study must take into account total funds flows, both positive and negative, that result during and beyond the system's expected life.

4) Continuous product improvement. Another factor that makes CRS different than other capital justification studies is that the system's benefits are not static. Organizations do not buy CRS software, install it, then let it sit as it is for three years. With the help of CRS it must be adapted as customer expectations, effective service processes, product offerings, organizational structures, and strategies evolve. A good example is an organization's forever changing Website. Consequently, CRS product functionality in Year 1 is not the same as in Year 3 - even with the same product. It is not unusual for a CRS to have hundreds of change requests pending when it first goes live, and to have thousands of changes posted throughout its useful life.

As such, projected benefits of CRS should reflect the continuously improving functionality of the system. Software that is harder to customize and integrate will deliver much less value than an open architecture that is easier to enhance.

5) Costing human behaviour. A final qualifier in estimating benefits of CRS is that analysts are attempting to put a value on human behaviour. This applies to both inside and outside the organization. Most CRS failures are not due to technical issues, but they are caused by refusal of employees or customers to use the system. Organizational change management issues trip-up many organizations. For example, end-user's foot dragging has driven up costs by 300 to 400 percent in some projects (Cooper 2005).

\section{Applying TCO approach when evaluating CRS efficiency}

The total cost of ownership (TCO) can be defined as the systematic quantification of all costs generated over the lifetime of a CRS project. The goal of TCO is to determine a figure that reflects the total cost of the investment, including one-time purchases and recurring costs, not just the initial start-up costs. The onetime and recurring costs are determined by looking at each stage of a project, starting with planning, analysis, design, configuration, programming and installation, and moving through migration, integration, training, and ongoing application support and maintenance (Nucleus Research 2007; Odellion Research 2006; Pisselo 2003).
The TCO equation is defined as the total cost of owning the CRS over a particular period of time (Odellion Research 2006):

$$
T C O=\frac{\sum_{t=1}^{t=\text { endofproject }} O T C+R C(t)}{P D},
$$

where $O T C$ - one-time costs - initial acquisition costs that are usually incurred at the beginning of the CRS implementation project in the form of software licences and hardware, or at the end of the project in the form of decommissioning costs to retire systems or applications; $R C(t)$ - recurring costs - ongoing CRS costs that are incurred on a periodic basis and originate from the maintenance, upgrades, and annual licensing fees, as well as support of CRS; $P D$ - project duration - the expected lifespan of CRM investment.

We recommend calculating TCO over a three - five year period to get a full understanding of the ongoing costs associated with CRS.

However, some companies do not include the project duration in the calculation, and thus the TCO is a summation of costs that are updated continually over the project's lifetime.

TCO has a number of strengths as a metric unit and it is important to calculate when evaluating technology, but it also has a number of weaknesses that need to be understood if company wants to use TCO results properly.

The strength of TCO is in providing an understanding of future costs that may not be apparent when an item is initially purchased.

Another benefit of the TCO methodology is its use as a benchmarking tool to compare CRS software vendors. Functionality of CRS software can be similar; however, the costs of it may vary drastically from vendor to vendor if including license fees, maintenance contracts, support, etc. Companies can then determine the TCO for each independent CRS software vendor and select the company that offers the least cost over the lifetime of the CRS software. The yearly TCO figure is an excellent indicator of the ongoing costs and is best used as a projection for budgeting purposes.

TCO has an important disadvantage because it completely ignores the benefits. For most companies the objective is not to choose the cheapest CRS software but to choose the software that provides the greatest benefit or return for the company. Many companies along with the press have focused on TCO as an important metric primarily because it is a tangible number. It is easy to point to a complete accounting of cost 
and make a decision based on a strategy of reducing expenditures. But CRS software, because it is used in key business processes, can have a dramatic impact on the bottom line and TCO only ensures a company to purchase the cheapest CRS, not the best.

Also, product with low acquisition costs and high maintenance is likely to be less attractive than one with higher acquisition and lower ongoing costs, but it may have a similar TCO over the period analysed.

In comparison with return on investment (ROI) and payback period of financial measurement methodologies, TCO is the best indicator of future CRS expenses. However, it is a weak indicator of risk associated with CRS and balance of cost versus return.

\section{Empirical research results}

Based on our empirical research results, only $25 \%$ of Lithuanian companies calculate TCO of CRS. Whereas half of Lithuanian companies are evaluating summation of all CRS costs (Fig. 1).

The majority of Lithuanian companies calculate CRS initial acquisition costs (Fig. 2). However, ongoing costs are calculated by less than a half companies.

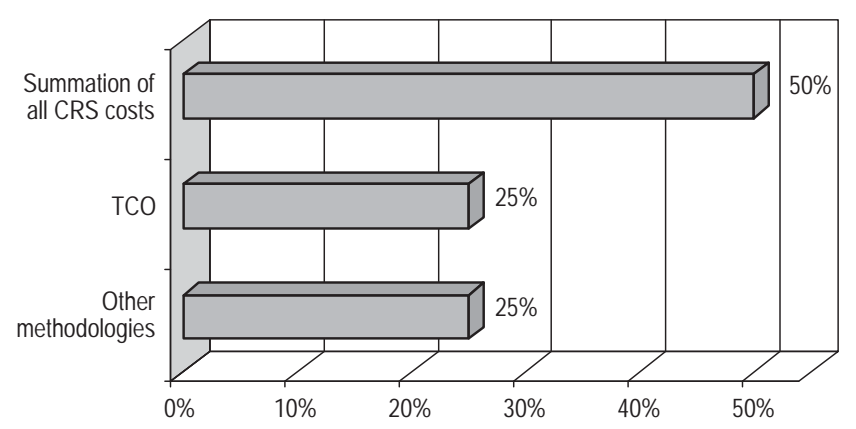

Fig. 1. CRS cost calculation methodologies used in Lithuanian companies
Based on our research results (Fig. 3), costs of initial CRS implementation works (analysis, design, installation, configuration, programming, integration, and migration) and CRS software licences represent almost half of the total cost of a CRS implementation project (47\%). Hardware (servers, computers) costs make 21\% of all total CRS implementation project costs. Employee training, internal staff work and external consulting service costs represent relatively a small part of total costs ( $8 \%, 8 \%$ and $7 \%$ respectively). CRS maintenance and support costs represent the smallest portion of total costs $(4 \%)$.

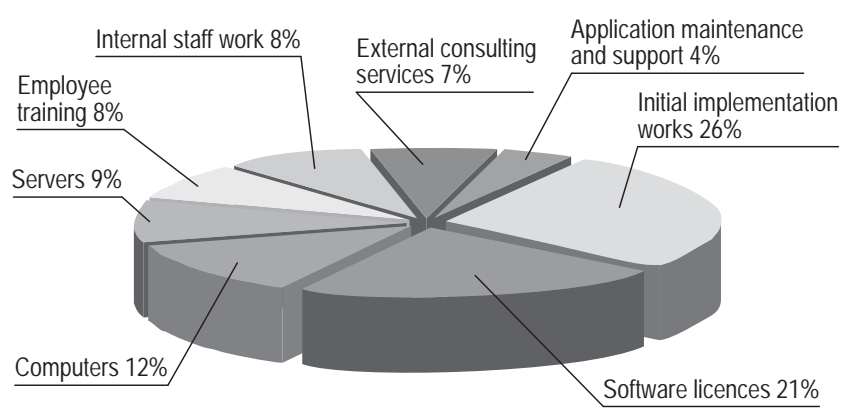

Fig. 3. CRS cost structure in Lithuanian companies

\section{Conclusions}

Calculating TCO and benefits, building a business case and applying financial measurement methodologies can help a company make right CRS investments solution and enable it to enjoy the results - instead of complaining that CRS fails to meet expectations. Therefore, an enterprise needs to assess the costs and benefits associated with CRS, then express that evaluation in financial metrics.

In addition, ongoing measurement of CRS benefits helps ensure that an enterprise receives expected advantages and achieves strategic objectives.

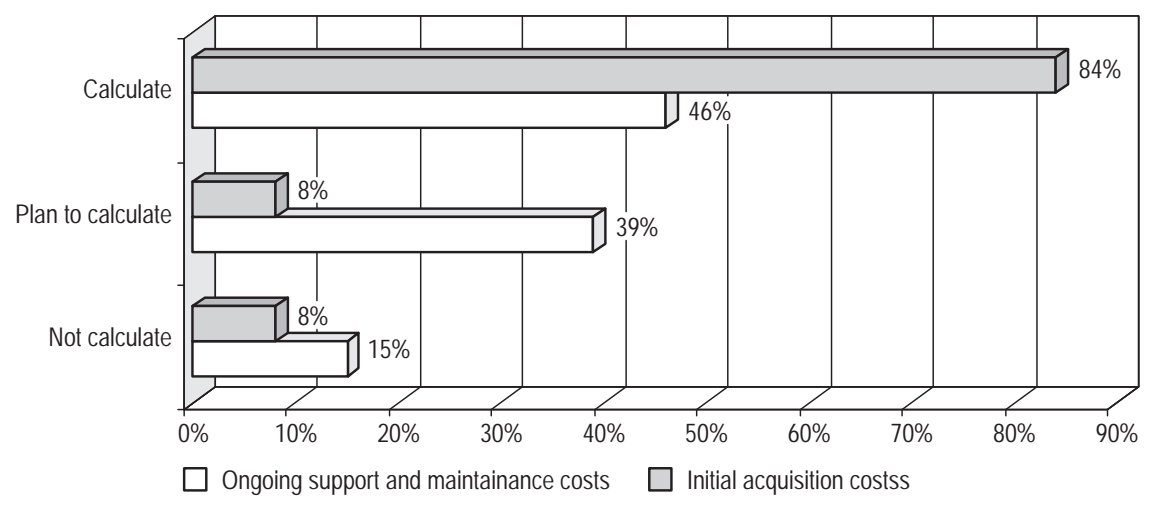

Fig. 2. Cost calculation of CRS initial acquisition and ongoing support and maintenance in Lithuanian companies 
The following guidelines should be used to manage TCO successfully (Gartner 2004): 1) build companies' TCO model to include consistent cost categories across all CRS projects for three-five years; 2) build bestand worst-case scenarios to determine TCO tolerances; 3) staff the CRS project with employees who have experience in building and measuring TCO; 4) include financial analysts on the project to assist with the approval process, and to provide insight for senior management during the life cycle of the initiative; 5) expect vendor proposals and internal staffing decisions to come before a final TCO calculation; 6) monitor and measure costs and spending throughout the project.

Application of a single TCO method is not sufficient for comprehensive (complex) evaluation of CRS efficiency because TCO completely ignores CRS investment benefits. A range of efficiency evaluation methods and models must be applied, like ROI, PP, NPV, IRR, EVA, etc.

\section{References}

Amerongen, T. 2004. Hitting the Mark with CRM [online] [accessed 31 September 2007]. Available from Internet: $<$ http://www.ideaca.com/assets/resources/crm/hitting_the mark_with_crm.pdf $>$.

Bordoloi, C. 2000. CRM Projects: A Framework for Success [online] [accessed 20 September 2007]. Available from Internet: $<$ http://www.mycustomer.com/download/4739/art068.pdf $>$.

Chase, P. 2001. Why CRM implementations fail and what to do about it [online] [accessed 20 September 2007]. Available from Internet: <http://www.crm.ie/pdf/white/Scribe_ WhyCRMImplementationsFail.pdf $>$.

Conner, A. 2001. Enterprise Integration to Support RealTime Analytics for Next Generation Customer Relationship Management [online] [accessed 7 December 2007]. Available from Internet: < http://www.crm-forum.com/library/art/ art-136/?edit>.

Cooper, K. 2005. Recommendations for Valid CRM Project Justification [online] [accessed 29 November 2007]. Available from Internet: <http://www.coopercomm.com/re-roippr. htm>.
Gartner, Inc. 2004. Justifying CRM Costs and Boosting Return on Investment [online] [accessed 29 September 2008]. Available from Internet: < http://www.gartner.com/research/ spr/attributes/attr_63667_429.pdf $>$.

Kim, H.; Kim, Y. 2007. A study of developing CRM Scorecard, in Proceedings of the 40th Annual Hawaii International Conference on System Sciences (HICSS'07), 1-10.

Korsakiene, R. 2009. The innovative approach to relationships with customers, Journal of Business Economics and Management 10(1): 53-60. doi:10.3846/1611-1699.2009.10.53-60

Korsakienė, R.; Tvaronavičius, V.; Mačiulis, A. 2008. Ryšių su klientais valdymas nekilnojamojo turto sektoriaus imonėse: privalumų ir ribojančių veiksnių tyrimas [Customer relationship management in the real estate companies], Verslas: teorija ir praktika [Business: Theory and Practice] 9(3): 190-198 (in Lithuanian).

doi:10.3846/1648-0627.2008.9.190-198

Nucleus Research, Inc. 2007. The Strengths and Weaknesses of Total Cost of Ownership [online] [accessed 31 September 2007]. Available from Internet: <http://www.nucleusresearch.com/research/a21.pdf $>$.

Odellion Research, Inc. 2006. Total Cost of Ownership (TCO) [online] [accessed 11 December 2007]. Available from Internet: $<$ http://www.odellion.com/pages/online $\% 20$ community/TCO $>$.

Pisselo, T. 2003. IT Value Chain Management - Maximizing ROI from IT Investments. Alinean, LLC: USA. 87 p.

Ramdas, N. 2001. Planning for a Successful CRM Initiative [online] [accessed 27 September 2007]. Available from Internet: <http://crmlibrary.crmcommunity.com/content/ display/71A5719E-BA82-4F2E-BAE33604EED91067. pdf $>$.

Silvon Software, Inc. 2005. Customer Relationship Analytics [online] [accessed 15 November 2007]. Available from Internet: <http://www.ebusinessforum.gr/old/content/downloads/wp0162.pdf>.

Sūdžius, V. 2007. The impact of customer relationship management on finance service development, Verslas: teorija ir praktika [Business: Theory and Practice] 8(3): 161-165 (in Lithuanian).

Tvaronavičius, V.; Tvaronavičienè, M. 2008. Role of fixed investments in economic growth of country: Lithuania in European context, Journal of Business Economics and Management 9(1): 57-65. doi:10.3846/1611-1699.2008.9.57-64 